\title{
SRF wt Allele
}

National Cancer Institute

\section{Source}

National Cancer Institute. SRF wt Allele. NCI Thesaurus. Code C91798.

Human SRF wild-type allele is located in the vicinity of $6 \mathrm{p} 21.1$ and is approximately $10 \mathrm{~kb}$ in length. This allele, which encodes serum response factor protein, plays a role in transcriptional regulation, cell proliferation, and cardiac development. 